\title{
Correction to "Tramadol Metabolism to O-Desmethyl Tramadol (M1) and N-Desmethyl Tramadol (M2) by Dog Liver Microsomes: Species Comparison and Identification of Responsible Canine Cytochrome P450s"
}

\begin{abstract}
In the above article [Perez Jimenez TE, Mealey KL, Grubb TL, Greene SA, Court MH (2016) Drug Metab Dispos 44:1963-1972 DOI: https://doi.org/10.1124/dmd.116.071902], the unit of measure at the top of the third, fourth, sixth and eighth columns in Table 1 were incorrectly provided as nmol/min per mg of protein for columns third and sixth and $\mathrm{ml} / \mathrm{min}$ per $\mathrm{mg}$ protein for columns fourth and eighth.
\end{abstract}

The correct unit of measurement in Table 1 for columns third and sixth is $\mathrm{pmol} / \mathrm{min}$ per $\mathrm{mg}$ protein and for columns fourth and eighth is $\mathrm{ml} / \mathrm{min}$ per $\mathrm{g}$ protein.

The HTML and PDF versions of the article have been corrected.

The author apologizes for this error and any inconvenience it may have caused. 